\title{
Impact of land use on coastline change of island cities: A case of Zhoushan Island, China
}

\author{
Yizhou Wu \\ School of Design and Architecture, Zhejiang University of Technology, China \\ zjuwyz@126.com
}

Shuai Wang

School of Design and Architecture, Zhejiang University of Technology, Hangzhou, China II50737534@qq.com

Jiacheng Yang

School of Design and Architecture, Zhejiang University of Technology, China

yjc2012@hotmail.com

\section{Siqin $\mathrm{Wu}$}

School of Design and Architecture, Zhejiang University of Technology, China 1825274046@qq.com

\section{Heyuan You}

School of public administration, Zhejiang University of Finance and Economics, China Department of City and Regional Planning, University of North Carolina at Chapel Hill, USA youheyuan@gmail.com (corresponding author)

\section{Yue Wang}

School of Public Administration, Zhongnan University of Economics and Law, China Department of City and Regional Planning, University of North Carolina at Chapel Hill, USA wangyue@zuel.edu.cn

\footnotetext{
Abstract: Anthropogenic activities have an important effect on the natural coastlines of island cities as a result of urbanization and population agglomeration in developing countries. In order to identify the relationships between land use and coastline changes in the typical island city, this study used land use data, remote sensing technology, and geographic information system (GIS) technology to analyze the land use situation and coastline changes in the coastal zone of Zhoushan Island in China. The results show that, from 2012 to 2017, the coastal land area of Zhoushan Island increased from $121.54 \mathrm{~km}^{2}$ to $126.00 \mathrm{~km}^{2}$. New agricultural land accounted for the highest proportion of total land use growth $(46.86 \%)$, followed by residential land, land for street, and transportation and industrial land. The length of the coastline increased from $137.98 \mathrm{~km}$ to $142.7 \mathrm{~km}$. The indicators of agricultural land, industrial land, land price, and production coastline had a significant positive impact on the rate of coastline changes. Moreover, the coastline was more than just a natural coastline but also had
} 
multiple functions in terms of production, daily living, leisure, and transportation. The study found that the rapid growth of tideland reclamation-based, land reclamation-based aquaculture, and the harbour/port construction-based logistics industry are the main reasons for the continuous changes in coastlines.

Keywords: China, coastline, islands, land use, remote sensing, Zhoushan Island

https://doi.org/10.24043/isj.125 • Received December 2019, accepted July 2020

(C) 2020 - Institute of Island Studies, University of Prince Edward Island, Canada.

\section{Introduction}

The coastline is known as the boundary between the land and the sea. Given global warming (Addo et al., 2008) and the joint influences of various factors, the coastline has been experiencing dynamic changes. Studies have identified two main factors that are responsible for changes in coastlines: anthropogenic activities and natural processes in coastal areas (Fletcher et al., 2011; Hanslow, 2007; Paterson et al., 2010; Turner, 2005; You, 2017; You et al., 2018; Zhang et al., 2004). Coastline erosion and the deterioration of island ecosystems have been caused by human development activities, including agricultural production activities (such as tideland reclamation and enclosure aquaculture), coastal projects (such as harbours/ports and floodwalls), development activities (such as solid waste landfills, lake dredging, and channel improvement), and tourism development, which occurs by destructing vegetation and marine ecosystems. The natural evolution of coastlines is also an important reason for their changes. Natural environmental processes, such as geological activities and sea-level rise, are important determinants for long-term changes in coastlines. During the past century, global warming has become a major factor that has induced changes in global and regional coastlines (Geng \& Hou, 2017). Island coastal zones are rich in natural and ecological resources. Therefore, the protection of island coastlines has very important social, economic, and eco-environmental benefits and is an inherent requirement for sustainable economic and social development (Wu et al., 2020; You, 2016a). In addition, the coastal zones of islands bear a variety of relics of the sea and land changes, natural traces of biological evolution and remnants of anthropogenic activities, which have extremely important scientific value and research significance.

The coastlines of island cities in China also face interference from social and economic development (You, 2016b). The natural ecological environment of the land is relatively fragile, and a shortage of land and freshwater resources exists, especially in the economically developing island cities in the eastern coastal areas. Therefore, changes in coastlines have been more intense, which have strongly affected the sustainable development of island cities. Accordingly, a detailed observation of the effect of land use on the changes in the coastal zones is very important in guiding the coastline changes of island cities. Zhoushan Island, which is in the economically developed Zhejiang Province of China, was selected as the focus for this study because it can reveal the impact of land use on coastline changes in island cities during China's rapid social-economic transition. 
Some studies have analyzed the relationship between coastline changes near harbour structures and various anthropogenic and natural factors, including the factors of economic growth, urban expansion, temperature, and precipitation (Samanta \& Paul, 2016; Sun et al., 2019; Wang, 2016). However, most of these factors are at the macroscopic level. Little analysis exists on the relationship between the use and lack of in-depth analyses of changes in island coastlines and coastal construction land. The current study used multi-temporal satellite data to describe the changes in Zhoushan Island's coastline from 2012 to 2017 and further compared the island's land use characteristics and the changes in various land use indicators in the island's $1 \mathrm{~km}$-wide buffer zone. The Zhoushan Island coastline was further classified on top of administrative regions to describe the trends and main reasons for coastline changes.

In this study, Zhoushan Island was selected as the empirical region to extract and classify the coastline, determine the quantitative indicators of the coastline, analyze the impact of land use on the coastline changes of island cities, and explain how land use affects coastline changes.

\section{Literature review}

\section{Research scale of coastline changes}

Coastlines have been extensively studied on national, regional, and urban scales. Zhu (2004) applied fractal theory to preliminarily explore the fractal characteristics and formation mechanism of the coastline of the bedrock coast in China on the basis of geographic information systems. On a regional scale, Adarsa et al. (2016) estimated and quantified the short-term changes in the coastline of the Bay of Bengal. On an urban scale, Aliyuddin and Damayanti (2019) studied the natural and anthropogenic factors that caused changes in the coastline of Serang of Banten Province. Studies on the evolution of coastlines are mostly at the meso level and rarely at national and urban scales.

\section{Analysis methods and techniques for the characteristics of coastline changes}

Characteristics of coastline changes include length fluctuation, morphological evolution, location change, use type change, and alterations in the land and sea space along the coastline. When analyzing changes in coastlines, qualitative or quantitative analysis can be performed based on simple basic statistics, such as an analysis of temporal and spatial variation characteristics of coastline length, shape, and location using length, sea, and land area, fractal dimension, and rate of change. Mishra et al. (2019) used open-source multi-temporal satellite images to assess the long- and short-term dynamics of the region along the coastline of Puri of Odisha, India, during the past 25 years. Andrieu (2018) mapped the vegetation and land cover changes in the coastal zone of West Africa and compared the current land use with that of previous decades. Dada et al. (2019) studied the long- and short-term changes in the coastline, land use, and land cover in Nigeria and proposed corresponding management measures and countermeasures.

The analysis of the change in coastline location plays an important role in the study of coastline changes. The main research methods are classified into qualitative and quantitative methods. Qualitative analysis is based on map overlay analysis to form a basic and qualitative understanding of changes in coastline locations. The quantitative analysis quantifies changes in coastline locations using numerical statistics, such as area and rate of change. According to the method for calculating the rate of change, quantitative analysis methods can be further categorized into simple- and complex-model analyses. Jayakumar and Malarvannan (2016) 
used 40 years of remote-sensing data and a topographic map of India to capture the coastline of northern Tamil Nadu in southern India, and then used overlay analysis to assess the erosion and accretion of the coastline. Cowart et al. (2011) adopted a point-based method to analyze the coastline changes of an estuary and the relevant parameters on regional (entire estuary) and local (eight cross-sections of the estuary) scales. She et al. (2017) combined a cellular automata model, a multi-agent model, and a coastline evolution prediction model to simulate land changes in coastal areas.

Analysis of the influencing factors of coastline changes

The influencing factors of coastline change can be classified into three categories: global environmental processes, coastal environmental processes, and anthropogenic activities. Cooper et al. (2008) assessed the potential impacts of persistent and intermittent floods caused by storms on the coastal areas of New Jersey in the United States; Kish and Donoghue (2013) introduced the major influences of storm frequency and intensity on changes in the northwest coast of Florida in the United States; Ai et al. (2019) analyzed the correlation of coastline length with the three artificial development factors of development intensity, development rate, and development density, and performed an in-depth analysis of the dynamic processes and anthropogenic mechanisms of coastline changes. The influence of global environmental processes on the coastal zone can be noted only after a long period, whereas coastal environmental processes and anthropogenic activities can affect coastline changes in a short period.

There are three ways to analyze the influencing factors of coastline change: the influencing factors and mechanism based on the actual changing process of coastline, the influencing factors based on the mathematical method and the analysis, and simulation of coastline change based on models. Li et al. (2018) used multi-temporal remote sensing data to extract information, such as the location, length, and tortuosity of coastlines of Xiangshan Harbor in China and Tampa Bay in the United States, for four periods from 1985 to 2015. The authors then constructed indicators for coastal artificialization and harbour landscape interferences to explore the influences of anthropogenic activities on evolutions of coastlines and landscapes on the harbours. Akinluyi et al. (2018) used a digital coastline analysis system to assess the coastline of Lagos, Nigeria, and relevant land use and land cover conditions. José et al. (2018) proposed a foredune erosion model that involved coastline changes to provide a reference for coastal planning. The analysis of the influencing factors of coastline changes gradually became digitized and more complicated.

\section{Study area and methods}

\section{Study Area}

The geographic location of Zhoushan Island is between $121^{\circ} 56^{\prime}-122^{\circ} 20^{\prime} \mathrm{E}$ and $29^{\circ} 56^{\prime}-30^{\circ}$ $11^{\prime} \mathrm{N}$, with an area of approximately $126 \mathrm{~km}^{2}$. As the main island of the Zhoushan Archipelago, Zhoushan Island is the largest island in Zhejiang Province and the fourth largest in China. The island has a residential population of nearly 420,000 and is $100-400 \mathrm{~m}$ above sea level. The surrounding coastal zone is dominated by alluvial plains, where most of the urban and rural construction land is distributed. The landform of the central region is dominated by hilly and mountainous terrains, and arable land is scattered across the low-lying 
coastal areas between the mountainous and hilly areas of Zhoushan Island. A road around the island, harbours/ports, and salt fields are distributed along the coastline (see Figure 1).

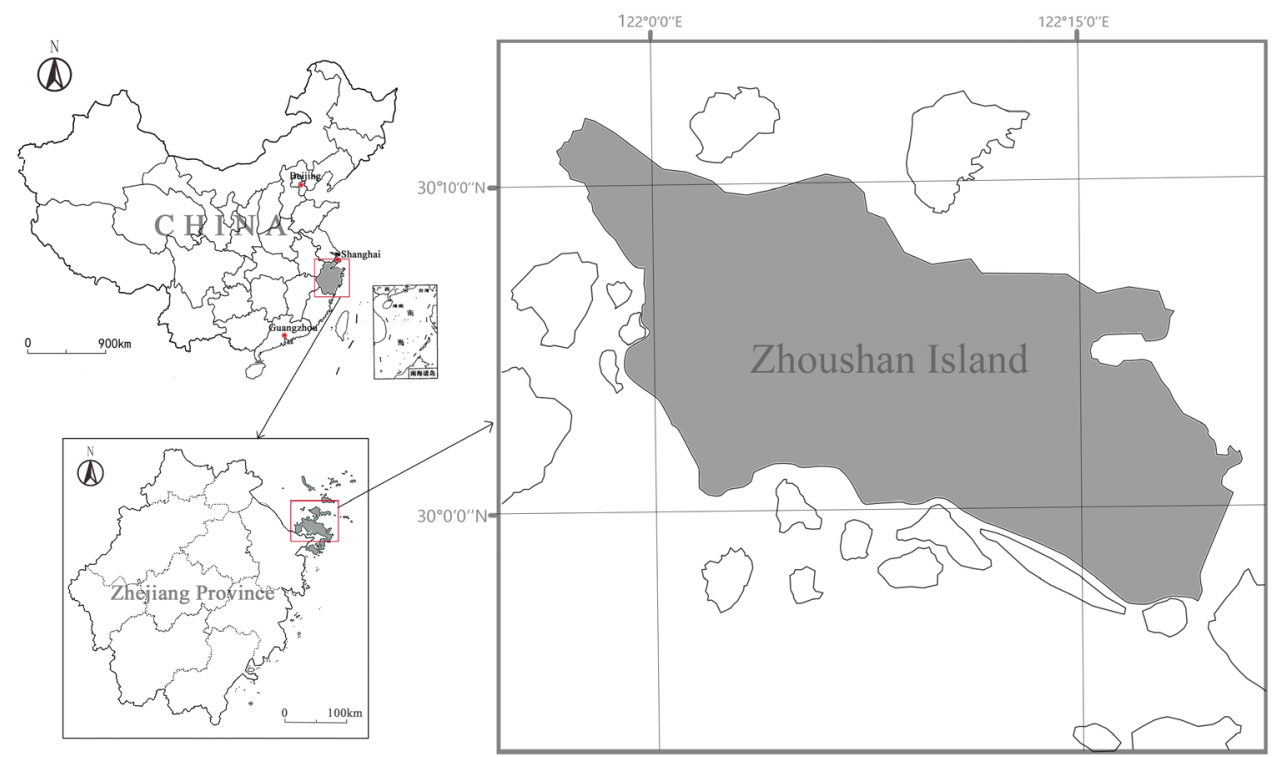

Figure 1: Study area of Zhoushan Island.

Zhoushan Island has 15 township-level administrative divisions, including 14 coastal townships. Using the Baiquan segment as the datum, the coastal zone of Zhoushan Island was divided into 30 segments, based on the principle that the segments have similar lengths and do not exceed the administrative boundaries of the townships. In this study, these segments were used as the analysis units (see Figure 2).

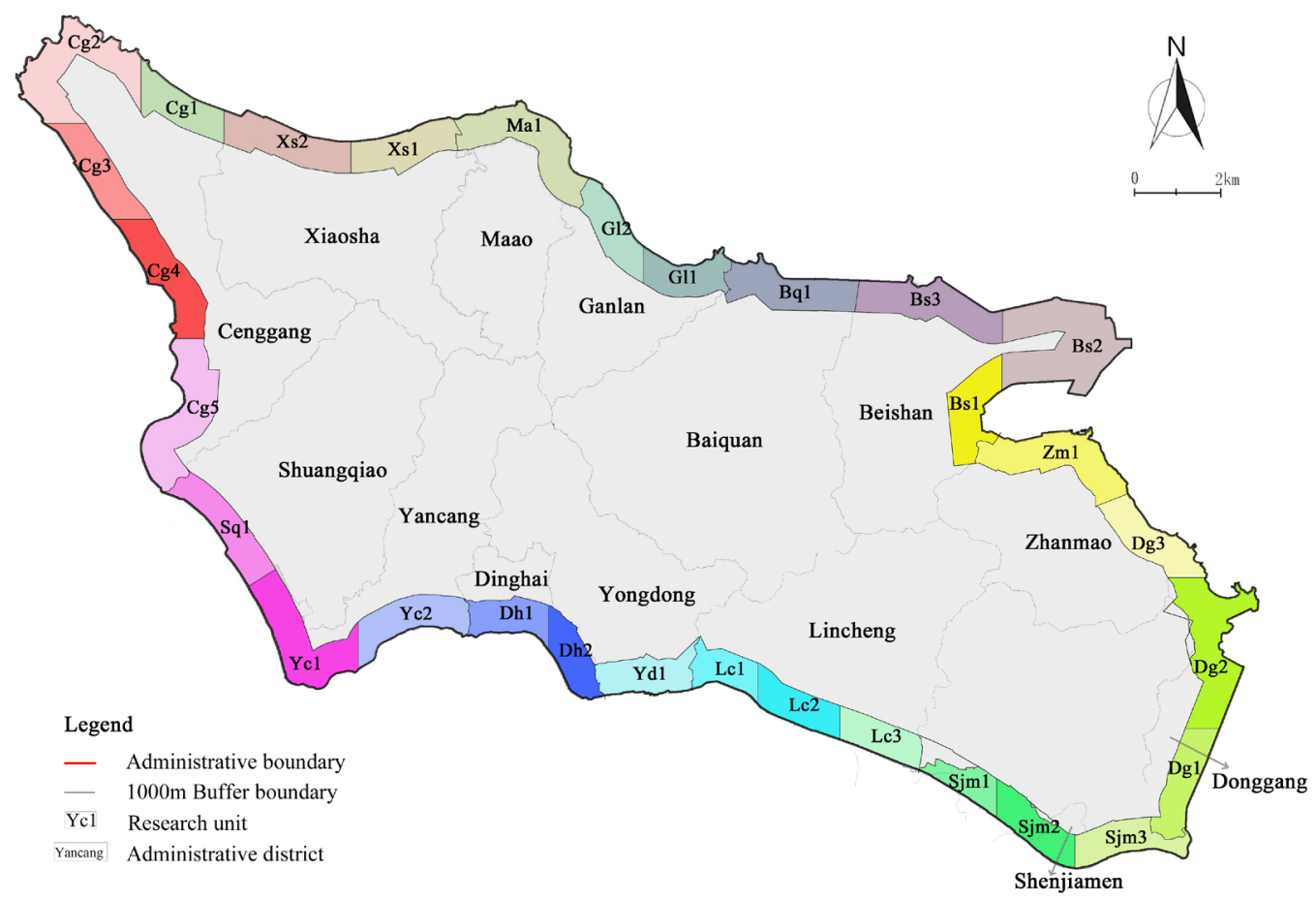

Figure 2: Coastal zone division of Zhoushan Island. 
Data

The Landsat 7 ETM+ imagery of the study area in 2012 and 2017 was acquired on the Geospatial Data Cloud (www.gscloud.cn) with a spatial resolution of $30 \mathrm{~m}$ (see Table 1). The data also include the General Land Use Planning of Zhoushan City, the 1:250,000 land use map of Zhoushan City, Zhoushan Statistical Yearbook and the administrative divisions of Zhoushan City.

Table 1: Description of remotely sensed data sources.

\begin{tabular}{cllll}
\hline Serial number & Satellites and sensors & Paths/Rows & Spatial resolution / M & Capture date \\
\hline 1 & Landsat7 ETM & $118 / 39$ & 30 & $2012 / 03 / 11$ \\
2 & Landsat7 ETM & $118 / 39$ & 30 & $2017 / 03 / 09$ \\
\hline
\end{tabular}

Firstly, pixels were randomly selected from the coastline and coastal zone of the original image, then the corresponding pixel points were found in the extracted image and the position changes between the two are compared. According to the number of displacement points, the extraction accuracy can be known. When the positions of two pixels overlap, the extraction effect is the best; if the two pixels are adjacent, the error is within the allowable range; however, when the two pixels do not overlap or are not adjacent, it means that the pixel extraction of this point is failed. In this study, 30 pixels were selected for each type of coastline and coastal land in each phase of the image, and compared with high-resolution satellite images and field survey results to verify the accuracy of Coastline Extraction and landuse monitoring results. Among them, the accuracy of sea/land attribute and land use type estimation was $91.5 \%$ and $82.5 \%$ respectively, and the results were overall accurate and reliable.

For land use change monitoring, we first use ENVI software to categorize the land use data of 2012 and 2017 and initially divide the land use on Zhoushan Island into forest land, water bodies, agricultural land (including mudflat), construction land, and other. Based on the high-resolution satellite maps of Zhoushan Island in 2012 and 2017, construction land was further divided into eight types of land use (residential, administration and public services, commercial and business facilities, industrial, logistics and warehouse, street and transportation, municipal utilities, and green space) using the visual interpretation and on-site check-up methods on basis of the 1:250,000 land use map of Zhoushan City.

\section{Coastline extraction and classification}

The 2012 and 2017 Landsat 7 ETM + imagery of Zhoushan Island were selected as the data source for extracting the coastline information. The raw images were pre-processed using ArcGis10.2 software to calculate the mean high tide line. The coastline of Zhoushan Island could be clearly distinguished and was extracted by automatic extraction and visual interpretation. The extracted coastline data were classified into three categorical variables: production coastline, residential coastline, and natural coastline (see Table 2). 
Table 2: Coastline type.

\begin{tabular}{|c|c|c|c|}
\hline Class I & Class II & Explanation & Classification \\
\hline \multirow{3}{*}{$\begin{array}{l}\text { Natural } \\
\text { coastline }\end{array}$} & Bedrock coastline & Land sea boundary of bedrock coast & \multirow{3}{*}{$\begin{array}{l}\text { Natural } \\
\text { coastline }\end{array}$} \\
\hline & Sandy coastline & Coastline of sand beach and gravel beach & \\
\hline & Silt muddy coastline & Coastline of silt or silty mudflats & \\
\hline \multirow{4}{*}{$\begin{array}{l}\text { Artificial } \\
\text { coastline }\end{array}$} & $\begin{array}{l}\text { Construction } \\
\text { coastline }\end{array}$ & Coastal line of urban construction land & \multirow{2}{*}{$\begin{array}{l}\text { Residential } \\
\text { coastline }\end{array}$} \\
\hline & $\begin{array}{l}\text { Artificial landscape } \\
\text { coastline }\end{array}$ & $\begin{array}{l}\text { Coastline of artificial park or landscape } \\
\text { protection belt }\end{array}$ & \\
\hline & Beach coastline & Coastline of tidal flat wetland farm & \multirow{2}{*}{$\begin{array}{l}\text { Production } \\
\text { coastline }\end{array}$} \\
\hline & Agricultural coastline & Coastline at side of garden and forest land & \\
\hline
\end{tabular}

Indicators for quantitative analysis of coastlines

a. The end point rate (EPR) analysis is an important module in the Digital Coastline Analysis System (DSAS), which is used to analyze the rate of coastline changes. EPR can reflect the characteristics of the net changes in coastlines, and the calculation formula is as follows:

$$
\mathrm{EPR}=\left(\mathrm{d}_{1}-\mathrm{d}_{2}\right) /\left(\mathrm{t}_{1}-\mathrm{t}_{2}\right)
$$

Where $\mathrm{d}_{1}$ (unit: $\mathrm{m}$ ) is the distance between the intersection of the vertical line and the earliest coastline to the baseline, $\mathrm{d}_{2}$ (unit: $\mathrm{m}$ ) is the distance from the intersection of the vertical line and the latest coastline to the baseline, $\mathrm{t}_{1}$ (unit: year) is the time corresponding to the earliest coastline, and $t_{2}$ (unit: year) is the time corresponding to the latest coastline (see Figure 3 ).

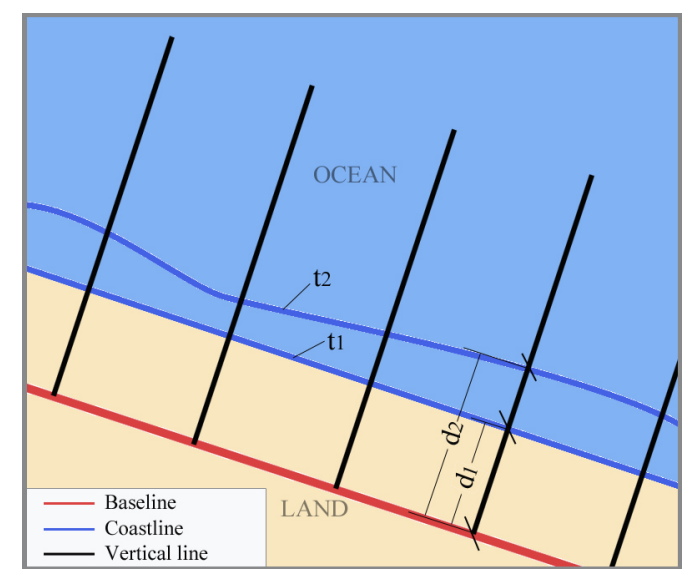

Figure 3: Scheme of the end point rate (EPR).

b. The tortuosity of the coastline, which refers to the ratio of the length of the coastline to the length of the polyline that follows the coastal contour (the length of the polyline within the $1 \mathrm{~km}$-wide buffer zone). The expression formula is as follows:

$$
\mathrm{K}=\mathrm{L} / \mathrm{L}^{\prime}
$$

Where $\mathrm{K}$ is the tortuosity of the coastline, $\mathrm{L}$ is the length of the coastline and $\mathrm{L}^{\prime}$ is the length of the polyline that follows the coastal contour.

c. Variables in statistics can be generally divided into numerical variables and categorical variables. The dynamic changes in the coastline are affected by the comprehensive effects of regional economic and social factors, and the internal driving mechanisms are complex. When selecting the influencing factors, because the total land area and land use types in the 30 coastal 
segments are different, the percentage is used as the unit of each land area indicator. Based on existing research results (Croft-White et al., 2017; Misra \& Balaji, 2015; Sengupta et al., 2018), an influencing factor system was constructed that includes factors that affected the change in the coastline of Zhoushan Island (see Table 3). The system consisted of six numerical variables and four categorical variables, which were used as the independent variables in the regression analysis. To eliminate the regression errors caused by the differences in dimensions and numerical values among different factors, the MATLAB normalization function, premnmx, was used to normalize each numerical variable, and the normalized data interval was $[-1,1]$.

Table 3: Type of quantitative indicator.

\begin{tabular}{|c|c|c|}
\hline Type & Impact indicator & Definition \\
\hline \multirow{7}{*}{$\begin{array}{l}\text { Numerical } \\
\text { variables }\end{array}$} & Industrial land change (\%) & $\begin{array}{l}\text { Difference of industrial land } \\
\text { proportion of each analysis unit in } \\
2017 \text { compared with that in } 2012 \text {. }\end{array}$ \\
\hline & Change in residential land (\%) & $\begin{array}{l}\text { Proportion difference of } \\
\text { residential land of each analysis } \\
\text { unit in } 2017 \text { compared with that } \\
\text { in } 2012 .\end{array}$ \\
\hline & Agricultural land change (\%) & $\begin{array}{l}\text { Proportion difference of } \\
\text { agricultural land of each analysis } \\
\text { unit in } 2017 \text { compared with that } \\
\text { in } 2012 .\end{array}$ \\
\hline & Building density change & $\begin{array}{l}\text { Change of building density in } \\
2017 \text { compared with that in } 2012 \text {. }\end{array}$ \\
\hline & Population change ( $10^{3}$ persons) & $\begin{array}{l}\text { Change of population in } 2017 \\
\text { compared with that in } 2012 .\end{array}$ \\
\hline & Land price change (yuan / m2) & $\begin{array}{l}\text { Change of land price in } 2017 \\
\text { compared with that in } 2012 .\end{array}$ \\
\hline & Density change of road network $(\mathrm{km} / \mathrm{km} 2)$ & $\begin{array}{l}\text { Change of road network density } \\
\text { in } 2017 \text { compared with that in } \\
2012 \text {. }\end{array}$ \\
\hline \multirow{4}{*}{$\begin{array}{l}\text { Categorical } \\
\text { variables }\end{array}$} & Wharf $(1 / 0)$ & Yes (1), no $(0)$ \\
\hline & Production coastline $(1 / 0)$ & Yes (1), no (0). \\
\hline & Residential coastline $(1 / 0)$ & Yes (1), no (0). \\
\hline & Natural coastline $(1 / 0)$ & Yes (1), no (0). \\
\hline
\end{tabular}




\section{Results}

\section{Land use change}

The results indicate that areas of the construction land and the agricultural land continue to grow and tend to expand towards the sea surface (see Table 4 and Figure 4). During 20122017 , construction land showed an overall increasing trend, with a total increase of $4.46 \mathrm{~km}^{2}$. Within that category, residential land, land for street and transportation, and industrial land increased considerably, with average annual growth rates of $0.14 \%, 0.13 \%$, and $0.12 \%$, respectively. The distribution of land for logistics and warehouses and municipal utilities remained relatively stable, and both land use types had an average annual growth rate of only $0.08 \%$. The areas of land for administration and public services, commercial and business facilities, and green space all grew somewhat. The agricultural land area also increased significantly. During 2012-2017, the total agricultural land area in the coastal zone of Zhoushan Island increased by $2.09 \mathrm{~km}^{2}$, with an average annual growth rate of $0.34 \%$. Spaces for daily living and production have been rapidly increasing as well.

Table 4: Land use change of Zhoushan Island coastal zone in 2012 and 2017.

\begin{tabular}{|c|c|c|c|c|}
\hline \multirow{2}{*}{\multicolumn{2}{|c|}{ Land use }} & \multicolumn{2}{|c|}{ Area $\left(\mathrm{km}^{2}\right)$} & \multirow{2}{*}{ Rate of change } \\
\hline & & 2012 & 2017 & \\
\hline \multicolumn{2}{|c|}{ Forest land } & 29.55 & 28.60 & $-0.78 \%$ \\
\hline \multicolumn{2}{|c|}{ Water bodies } & 2.94 & 2.89 & $-0.04 \%$ \\
\hline \multicolumn{2}{|c|}{ Agricultural land } & 26.45 & 28.54 & $+1.72 \%$ \\
\hline \multicolumn{2}{|c|}{ Other land } & 21.27 & 21.03 & $-0.20 \%$ \\
\hline \multirow{8}{*}{ 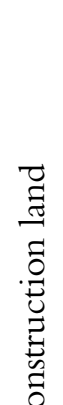 } & Residential & 9.89 & 10.72 & $+0.68 \%$ \\
\hline & Administration and public services & 1.27 & 1.45 & $+0.15 \%$ \\
\hline & Commercial and business facilities & 4.54 & 5.17 & $+0.52 \%$ \\
\hline & Industrial & 13.47 & 14.19 & $+0.59 \%$ \\
\hline & Logistics and warehouse & 0.24 & 0.29 & $+0.04 \%$ \\
\hline & Street and transportation & 4.34 & 5.12 & $+0.64 \%$ \\
\hline & Municipal utilities & 0.92 & 0.98 & $+0.05 \%$ \\
\hline & Green space & 6.66 & 7.02 & $+0.30 \%$ \\
\hline
\end{tabular}

Total area of the island $\quad 121.54 \quad 126 \quad+3.67 \%$




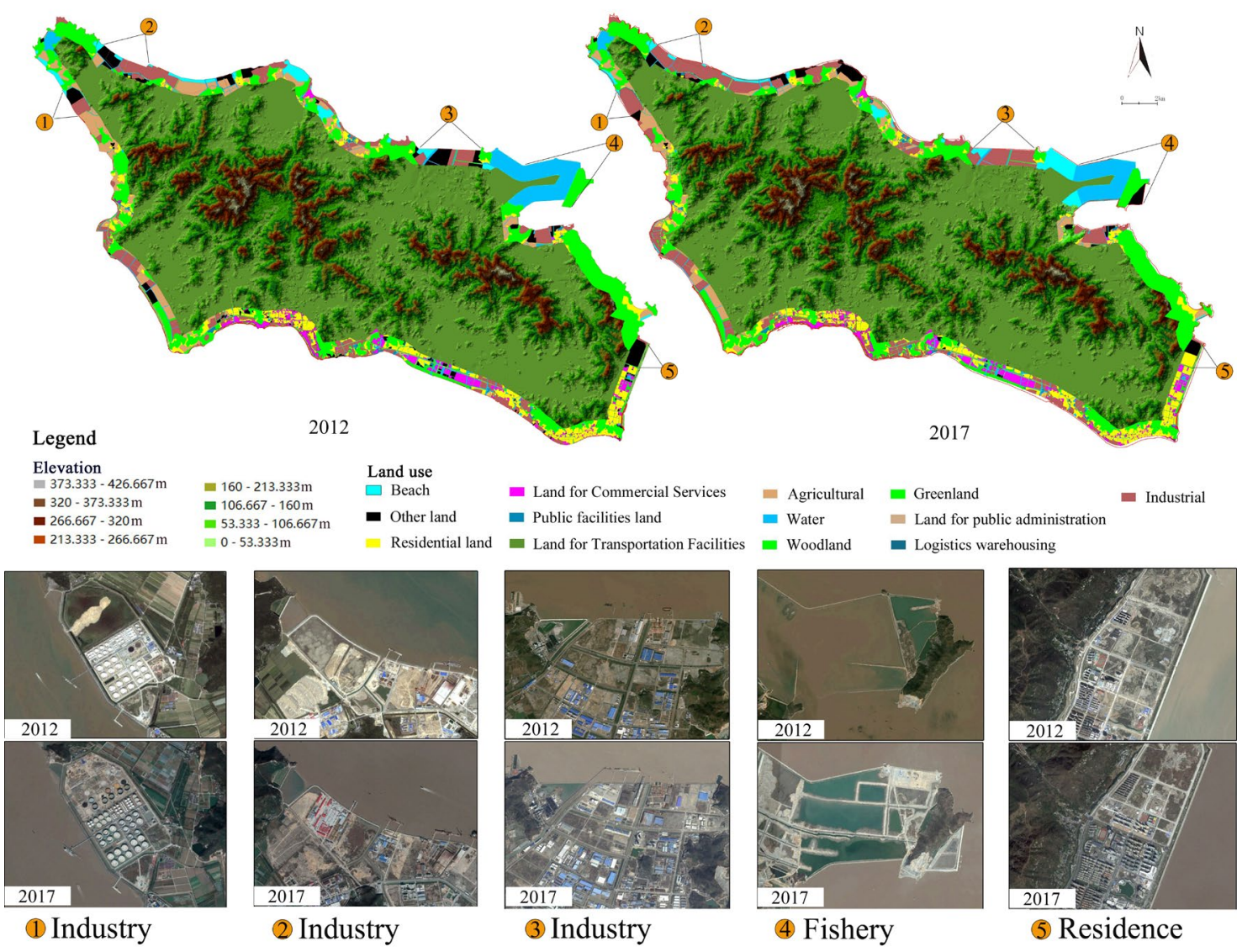

Figure 4: Land use change of Zhoushan Island coastal zone in 2012 and 2017.

\section{Coastline changes}

The overall length of the coastline exhibited an increasing trend, whereas the length of the local coastline decreased. From 2012 to 2017, because of the joint influences of anthropogenic development activities and the natural evolution of coastlines, the total coastline length of Zhoushan Island increased from $137.98 \mathrm{~km}$ to $142.7 \mathrm{~km}$, with an average annual increase of $0.94 \mathrm{~km}$ (see Figure 5 and Table 5). The fastest growth in coastline length was in the Beichan segment, with an average annual growth rate of $2.97 \%$, followed by those of the Maao and the Xiaosha segments, which had average annual growth rates of $2.59 \%$ and $2.21 \%$, respectively. The coastline lengths of the Shuangqiao, Dinghai, Yongdong, Lincheng, Shenjiamen, Donggang, Zhanmao, Baiquan, and Ganlan segments all increased slightly. It is worth noting is that the coastline lengths of the Cengang and Yancang segments were shortened to a certain extent. The changes in areas for the different land use types of each segment indicated that these land areas did not decrease. The decrease in the coastline lengths was caused by the increased anthropogenic intervention activities that reduced the tortuosity of the coastline in 2017 relative to 2012. The coastline's overall length continued to increase and was prone to seaward expansion. 

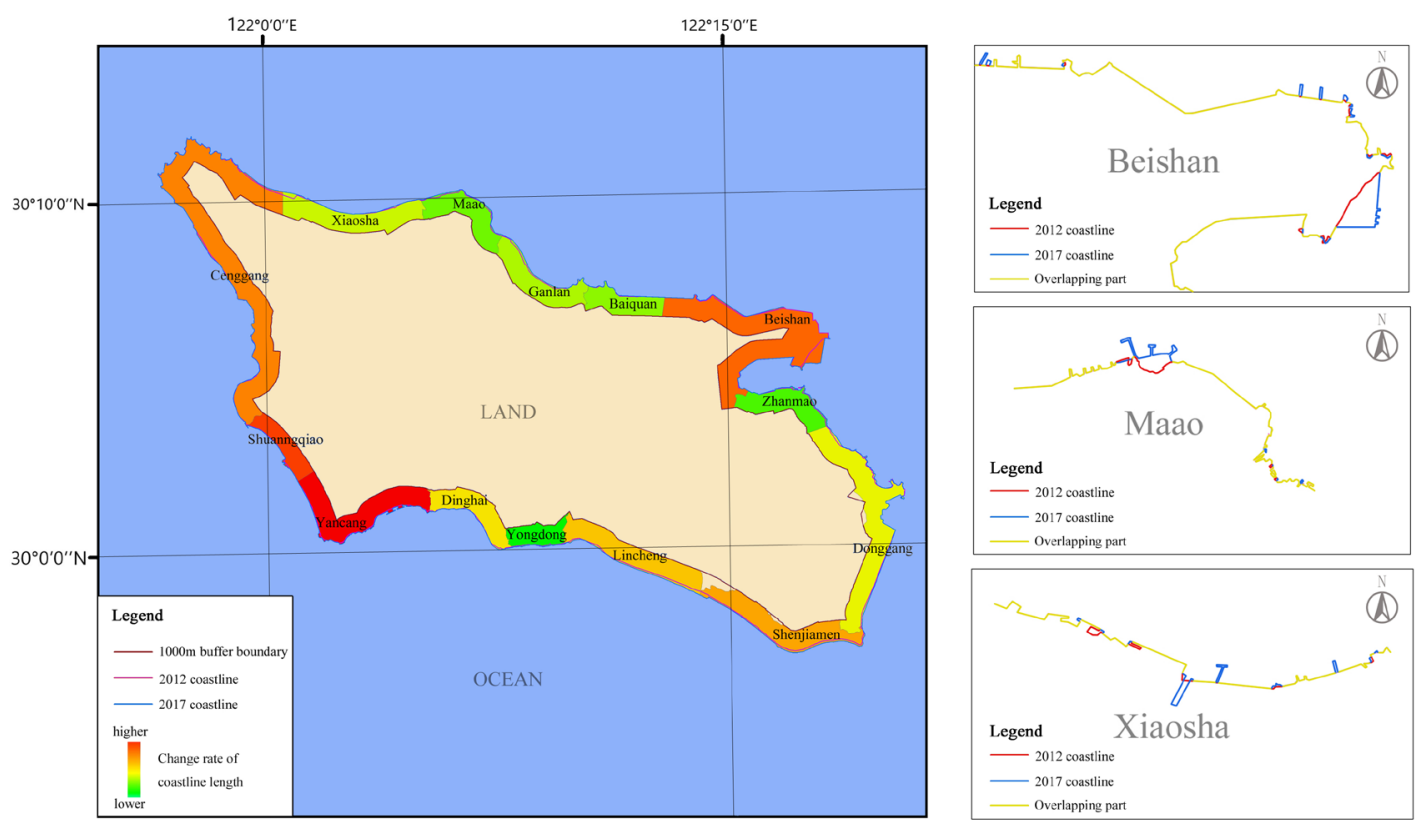

Figure 5: Coastline changes of Zhoushan Island in 2012 and 2017.

Table 5: Coastline changes of Zhoushan Island in 2012 and 2017.

\begin{tabular}{llll}
\hline \multirow{2}{*}{ Zone } & \multicolumn{2}{l}{ Length of coastline $(\mathrm{km})$} & \multirow{2}{*}{ Average change rate (\%) } \\
\cline { 2 - 3 } & 2012 & 2017 & -0.15 \\
\hline Cenggang & 28.09 & 27.88 & 0.08 \\
Shuangqiao & 10.06 & 10.10 & -0.05 \\
Yancang & 4.19 & 4.18 & 0.11 \\
Dinhai & 5.55 & 5.58 & 0.12 \\
Yongdong & 3.33 & 3.35 & 0.13 \\
Lincheng & 7.92 & 7.97 & 0.19 \\
Shenjiamen & 10.79 & 10.89 & 0.09 \\
Donggang & 12.92 & 12.98 & 0.25 \\
Zhanmao & 11.81 & 11.96 & 2.97 \\
Beichan & 18.73 & 21.51 & 0.37 \\
Baiquan & 4.92 & 5.01 & 0.24 \\
Ganlan & 6.64 & 6.72 & 2.59 \\
Maao & 5.26 & 5.94 & 2.21 \\
Xiaosha & 7.77 & 8.63 & \\
\hline
\end{tabular}

The coastline EPR is an important parameter for predicting the future trend of coastline changes. The EPR indicator was used to study the coastline of Zhoushan Island during 20122017. A positive value indicates the seaward expansion of the coastline, and a negative value indicates the landward retreat of the coastline. The results show that the coastline of Zhoushan Island generally exhibited a seaward expansion tendency, but different segments had different characteristics. The coastline change of the Beichan segment was the fastest; the coastlines of the Maao, Xiaosha, Lincheng, Shenjiamen, and Donggang segments, which have relatively high levels of urbanization, also expanded rapidly towards the sea; the change in the coastline of the Yongdong segment was relatively slow; and the coastline of the Dinghai segment will basically remain unchanged in a short period. 


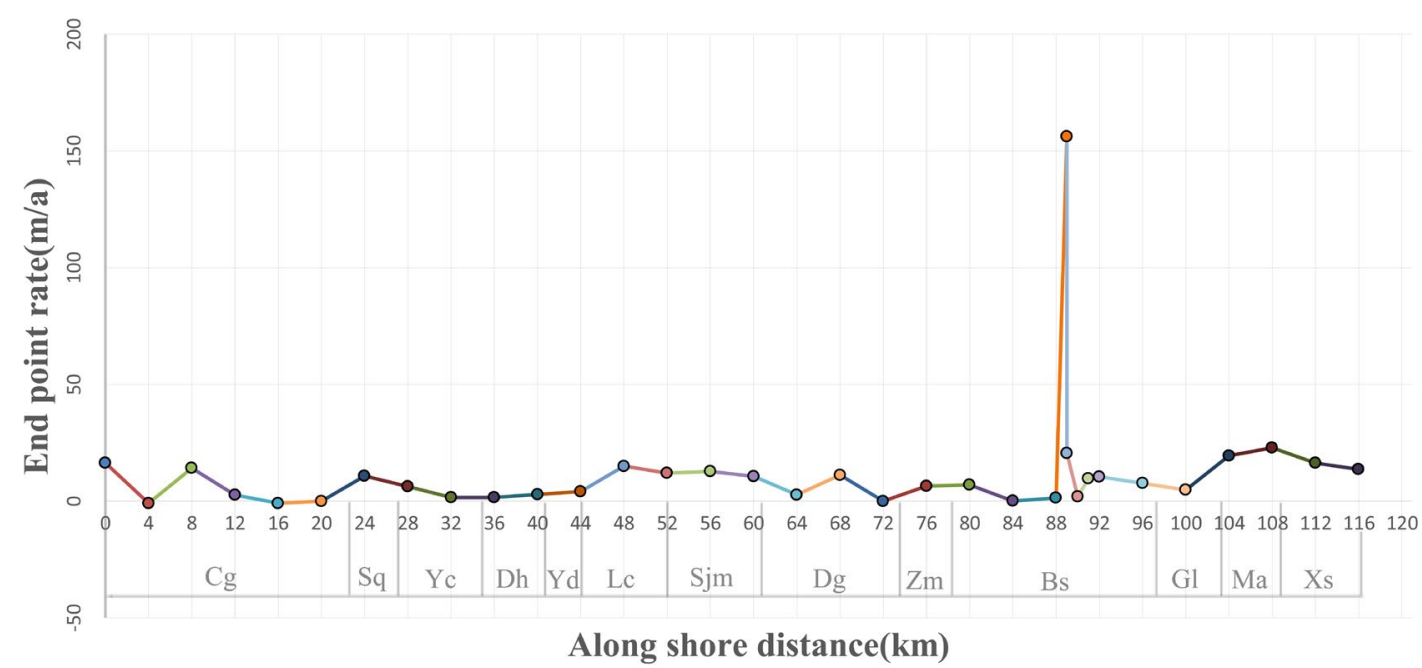

Figure 6: Changes in the EPR of the coastline of Zhoushan Island during 2012-2017.

\section{Influencing factors of coastline changes}

Changes in coastlines occur through the joint influences of anthropogenic factors and natural evolution. To achieve a quantitative comparison, a linear regression model was used to simulate the relationship between each land use indicator (Table 3) and the EPR of the coastline. The results (Table 6) indicated that the four indicators of agricultural land change, industrial land change, land price change and production coastline had a significant positive impact on the rate of coastline changes. In contrast, changes in residential land use, building density, road network density and population, and the residential coastline and natural coastline indicators had an insignificant influence on the rate of coastline changes.

Table 6: Regression results of factors affecting coastline changes. Note: Dependent variable: EPR.

\begin{tabular}{|c|c|c|c|c|c|c|}
\hline \multicolumn{2}{|c|}{ Model } & \multicolumn{2}{|c|}{$\begin{array}{l}\text { Non-standardized } \\
\text { coefficient }\end{array}$} & \multirow{2}{*}{$\begin{array}{l}\text { Standard } \\
\text { coefficient } \\
\text { Trial version }\end{array}$} & \multirow[t]{2}{*}{$\mathrm{t}$} & \multirow[t]{2}{*}{ Sig. } \\
\hline & & $\mathrm{B}$ & Standard error & & & \\
\hline \multirow{11}{*}{1} & (Constant) & 66.106 & 43.015 & & 1.537 & 0.141 \\
\hline & Industrial land change $\left(\mathrm{km}^{2}\right)$ & 6.935 & 1.802 & 0.506 & 3.848 & 0.001 \\
\hline & Residential land change $\left(\mathrm{km}^{2}\right)$ & 1.483 & 1.335 & 0.137 & 1.111 & 0.280 \\
\hline & Agricultural land change $\left(\mathrm{km}^{2}\right)$ & 1.048 & 0.228 & 0.530 & 4.606 & 0.000 \\
\hline & Building density change & -65.173 & 46.087 & -0.218 & -1.414 & 0.173 \\
\hline & Population change ( $10^{3}$ persons) & 172.370 & 122.650 & 2.070 & 1.405 & 0.176 \\
\hline & Land price change $\left(\right.$ yuan $/ \mathrm{m}^{2}$ ) & 207.329 & 55.073 & 0.396 & 3.765 & 0.001 \\
\hline & Road network density change $\left(\mathrm{km} / \mathrm{km}^{2}\right)$ & -23.572 & 11.703 & -.279 & -2.014 & 0.058 \\
\hline & Production coastline $(1 / 0)$ & 2.816 & 0.930 & 0.349 & 3.029 & 0.007 \\
\hline & Residential coastline $(1 / 0)$ & 0.461 & 1.133 & 0.066 & 0.407 & 0.689 \\
\hline & Natural coastline $(1 / 0)$ & -0.495 & 1.419 & -0.056 & -.349 & 0.731 \\
\hline \multirow[t]{2}{*}{2} & $\mathrm{R}$ & $\mathrm{R}^{2}$ & Adjust $\mathrm{R}^{2}$ & & $\begin{array}{l}\text { Error of } \\
\text { standard }\end{array}$ & f est. \\
\hline & 0.915 & 0.838 & 0.753 & & 1.729 & \\
\hline
\end{tabular}




\section{Discussion and conclusion}

\section{Trends in land use change on Zhoushan Island}

Zhoushan City is a prefecture-level city with the smallest land area in Zhejiang Province, and its total land area is only $1.4 \%$ of the total land area of the province. The territory is mountainous and hilly, with undulating terrain, and the available land resource is very limited. Most of the land with a slope greater than $15^{\circ}$ belongs to the island's ecological protection forest, which is not suitable for development. In terms of distribution, the agricultural land is mainly concentrated between the mountainous and hilly regions of Zhoushan Island and in the low-lying coastal areas; the construction land is mainly distributed in east Zhoushan Island and the low-lying coastal area in south Zhoushan Island, and, for the most part, the agricultural land overlaps with the expansion area of the construction land. In recent years, construction land has tended to expand towards the west and north coasts of the island. As a result of the contradiction between large residential population and small land area, the construction and agricultural lands tend to expand seaward.

\section{Hidden causes for the impact of land use on coastline changes}

In the current study, the coastline of Zhoushan Island generally exhibited tendency toward seaward expansion. The coastline change of the Beichan segment was the fastest, mainly caused by the expansion of agricultural production activities such as land reclamation; the coastlines of the Maao, Xiaosha, Lincheng, Shenjiamen, and Donggang segments, which have relatively high levels of urbanization, also expanded rapidly towards the sea; and the change in the coastline of the Yongdong segment was relatively slow because of its undeveloped economy, small population, and low anthropogenic disturbances. The coastline of the Dinghai segment, however, will remain relatively unchanged in a short period because of its well-developed economy, mature urban development, and concrete dykes constructed along the coastline.

Production activities, such as industrial and agricultural activities, are key factors that affect coastline changes (Wu et al., 2017; Wu et al., 2018). The rapid growth of agricultural land on Zhoushan Island, especially the expansion of mudflats and salt fields, had a significant impact on fluctuations in the coastline length. The significant growth of industrial land, especially the construction of harbours and/or ports, had a strong impact on coastline changes. Areas with significant changes in land prices often have population agglomeration and land appreciation brought about by urbanization, and the development and construction of a large number of cities also mean that natural coastlines are being converted into artificial coastlines. Production coastlines mainly include mudflats and agricultural coastlines, and the vulnerability of these types of coastlines makes them most susceptible to changes in the natural environment. Although the residential land area on Zhoushan Island experienced a relatively significant increase, this type of land is rarely close to the shore, and the possibility of large changes in a short period is low. Residential land use has a weaker impact on coastline changes than does reclamation for agricultural use and industrial land use for the construction of harbours or ports. Therefore, the econometric results showed that changes in residential land use, building density, road network density and population, and non-artificial changes in daily living indicators had an insignificant impact on the rate of coastline changes.

Changes in agricultural land use, industrial land use, land prices, and production coastline indicators have significant effects on the rate of coastline changes. In contrast, 
although the construction land area, such as residential land, increases to a certain degree, construction land use had little influence on coastline changes given the government's control over the growth indicator and the short-term relative stability of construction land. The anthropogenic activities that cause coastline changes mainly include urban production, daily living activities and infrastructure construction, reclamations for agricultural development, harbour/port construction, and expansion of mudflats and salt fields. The natural processes that cause coastline changes mainly include estuary sedimentation and seawater intrusion (Saranathan et al., 2011). Compared with anthropogenic development activities, natural evolution has less of an impact on the coastline of Zhoushan Island.

\section{Method limitations}

The spatiotemporal distribution of the coastline of Zhoushan Island during 2012-2017 was acquired using remote sensing and GIS technology. The relationship between land use change in the coastal zone, the spatiotemporal relationship between coastline changes and land use change indicators and the cause of dynamic changes in the coastline were analyzed. Changes in agricultural land use, industrial land use, land prices, and production coastline indicators had a significant influence on the rate of coastline changes. The rapid growth of tideland reclamation-based and land reclamation-based aquaculture and the harbour/port construction-based industrial land use was the main reason for Zhoushan Island's coastline changes in recent years. This study can not only guide island cities in finding the best management and development measures during the development of coastal zones but also strongly promote the rational use of island resources and improve use efficiency and quality (Ahmad, 2018). However, the method used in this study still has a deficiency: the ebb and flow of seawater is causing the coastline to constantly change. The coastline extraction method used in this study needs to be further optimized, and further studies are needed to classify the land use types and grades and determine the indicators.

\section{Acknowledgments}

This research received financial support from the National Natural Science Foundation of China (51578507 and 71874151), The Philosophy and Social Sciences Foundation of Zhejiang (16NDJC203YB), the Humanity and Social Science Foundation of Ministry of Education of China (18YJA630134), and the Zhejiang Provincial Natural Science Foundation of China (LY18G030031).

\section{References}

Addo, K.A., Walkden, M., \& Mills, J.P. (2008). Detection, measurement and prediction of coastline recession in Accra, Ghana. ISPRS Journal of Photogrammetry and Remote Sensing, 63(5), 543-558. https://doi.org/10.1016/j.isprsjprs.2008.04.001

Ahmad, E. (2018). Governance models and policy framework: Some Chinese perspectives. Journal of Chinese Governance, 3(2), 129-157. https://doi.org/10.1080/23812346.2018.1455414 
Ai, B., Zhang, R., Zhang, H., Ma, C., \& Gu, F. (2019). Dynamic process and artificial mechanism of coastline change in the Pearl River Estuary. Regional Studies in Marine Science, 30, 100715. https://doi.org/10.1016/j.rsma.2019.100715

Akinluyi, F.O., Adebola, A.O., \& Adeseko, A.A. (2018). Assessment of coastline and associated land use/land cover changes along part of Lagos coastline, Nigeria. Contemporary Trends in Geoscience, 7(1), 59-71. https://doi.org/10.2478/ctg-2018-0004

Aliyuddin G., \& Damayanti A. (2019) Coastline changes in Serang City, Banten Province. IOP Conference Series: Earth and Environmental Science, 248(1), 012062. https://doi.org/10.1088/1755-1315/248/1/012062

Andrieu, J. (2018). Land cover changes on the West-African coastline from the Saloum Delta (Senegal) to Rio Geba (Guinea-Bissau) between 1979 and 2015. Nephron Clinical Practice, 51(1), 314-325. https://doi.org/10.1080/22797254.2018.1432295

Cooper M.J.P., Beevers, M.D., \& Oppenheimer, M. (2008). The potential impacts of sea level rise on the coastal region of New Jersey, USA. Climatic Change, 90(4), 475-492. https://doi.org/10.1007/s10584-008-9422-0

Cowart, L., Corbett, D.R., \& Walsh, J.P. (2011). Coastline change along sheltered coastlines: Insights from the Neuse River estuary, NC, USA. Remote Sensing, 3(7), 1516-1534. https://doi.org/10.3390/rs3071516

Croft-White, M.V., Cvetkovic, M., Rokitnicki-Wojcik, D., Midwood, J.D., \& Grabas, G.P. (2017). A coastline divided: Twelve-year water quality and land cover trends in Lake Ontario coastal wetlands. Journal of Great Lakes Research, 43(6), 1005-1015. https://doi.org/10.1016/j.jglr.2017.08.003

Dada, O.A., Agbaje, A.O., Adesina, R.B., \& Asiwaju-Bello, Y.A. (2019). Effect of coastal land use change on coastline dynamics along the Nigerian Transgressive Mahin mud coast. Ocean \& Coastal Management, 168, 251-264. https://doi.org/10.1016/j.ocecoaman.2018.11.014

Fletcher, C.H., Romine, B.M., Genz, A.S., Barbee, M.M., Dyer, M., Anderson, T.R., Lim, S.C., Vitousek, S., Bochiocchio, C., \& Richmond, B.M. (2011). National assessment of coastline change; historical coastline change in the Hawaiian islands [U.S. Geological Survey open-file report no. 2011-1051]. https://pubs.usgs.gov/of/2011/1051/pdf/ofr2011-1051 report 508.pdf

Geng T., \& Hou X. (2017). A review of research on coastline changes. Chinese Journal of Ecology, 4, 1170-1182.

Hanslow, D.J. (2007). Beach erosion trend measurement: A comparison of trend indicators. Journal of Coastal Research, 50, 588-593.

Jayakumar, K., \& Malarvannan, S. (2016). Assessment of coastline changes over the Northern Tamil Nadu Coast, South India using WebGIS techniques. Journal of Coastal Conservation, 20(6), 477-487. https://doi.org/10.1007/s11852-016-0461-9

Kish, S.A., \& Donoghue, J.F. (2013). Coastal response to storms and sea-level rise: Santa Rosa Island, northwest Florida, U.S.A. Journal of Coastal Research, 63, 131-140. https://doi.org/10.2112/si63-012.1

Li, J., Liu, Y., Pu, R., Yuan, Q., Shi, X., Guo, Q., \& Song, X. (2018). Coastline and landscape changes in bay areas caused by human activities: A comparative analysis of Xiangshan Bay, China and Tampa Bay, USA. Journal of Geographical Sciences, 28(8), 1127 1151. https://doi.org/10.1007/s11442-018-1546-1 
Mishra, M., Chand, P., Pattnaik, N., Kattel, D.B., Panda, G.K., Mohanti, M., Baruah, U.D., Chandniha, S.K., Achary, S., \& Mohanty, T. (2019). Response of long- term to shortterm changes of the Puri coastline of Odisha (India) to natural and anthropogenic factors: A remote sensing and statistical assessment. Environmental Earth Sciences, 78(11), 338. https://doi.org/10.1007/s12665-019-8336-7

Misra, A., \& Balaji, R. (2015). A study on the coastline changes and land-use/land-cover along the south Gujarat coastline. Procedia Engineering, 116, 381-389. https://doi.org/10.1016/j.proeng.2015.08.311

Paterson, S.K., O’Donnell, A., Loomis, D.K., and Hom, P. (2010). The social and economic effects of coastline change: North Atlantic, South Atlantic, Gulf of Mexico, and Great Lakes regional overview: Final Report. Human Dimensions of Natural Resource Management Research Unit, Department of Natural Resources Conservation, University of Massachusetts.

Samanta, S., \& Paul, S.K. (2016). Geospatial analysis of coastline and land use/land cover changes through remote sensing and GIS techniques. Modeling Earth Systems and Environment, 2(3), 108. https://doi.org/10.1007/s40808-016-0180-0

Saranathan, E., Chandrasekaran, R., Soosai Manickaraj, D., \& Kannan, M. (2011). Coastline changes in Tharangampadi village, Nagapattinam district, Tamil Nadu, India-A Case Study. Journal of the Indian Society of Remote Sensing, 39(1), 107-115. https://doi.org/10.1007/s12524-010-0052-4

Sengupta, D., Chen, R., \& Meadows, M.E. (2018). Building beyond land: An overview of coastal land reclamation in 16 global megacities. Applied Geography, 90, 229-238. https://doi.org/10.1016/j.apgeog.2017.12.015

She, J., Guan, Z., Cai, F., Pu, L., Tan, J., \& Chen, T. (2017). Simulation of land use changes in a coastal reclaimed area with dynamic coastlines. Sustainability, 9(3), 431. https://doi.org/10.3390/su9030431

Sun, X., Wu, M., Tian, J., Lu, J., Yu, H., Song, F., et al. (2019). The temporal and spatial changes and driving forces of Weihai coastline in recent 30 years. Chinese Journal of Applied Oceanography, 38(2), 61-68.

Turner, B.I.L. (2005). Coastline definition and detection: A review. Journal of Coastal Research, 21(4), 688-703.

Wang, Z.W.J. (2016). Coastline and land use change detection and analysis with remote sensing in the Pearl River estuary gulf. Scientia Geographica Sinica, 36(12), 1903-1911.

Wu, Y., Fan, P., \& You, H. (2018). Spatial evolution of producer service sectors and its influencing factors in cities: A case study of Hangzhou, China. Sustainability, 10(4), 975. https://doi.org/10.3390/su10040975

Wu, Y., Fan, P., Li, B., Ouyang, Z., Liu, Y., \& You, H. (2017). The effectiveness of planning control on urban growth: Evidence from Hangzhou, China. Sustainability, 9(5), 855. https://doi.org/10.3390/su9050855

Wu, Y., Zhang, T., Zhang, H., Pan, T., Ni, X., Grydehøj, A., \& Zhang, J. (2020). Factors influencing the ecological security of island cities: A neighborhood-scale study of Zhoushan Island, China. Sustainable Cities and Society, 102029. https://doi.org/10.1016/j.scs.2020.102029 
You, H. (2017). Agricultural landscape dynamics in response to economic transition: Comparisons between different spatial planning zones in Ningbo region, China. Land Use Policy, 61, 316-328. https://doi.org/10.1016/j.landusepol.2016.11.025

You, H. (2016a). Characterizing the inequalities in urban public green space provision in Shenzhen, China. Habitat International, 56, 176-180. https://doi.org/10.1016/j.habitatint.2016.05.006

You, H. (2016b). Quantifying megacity growth in response to economic transition: A case of Shanghai, China. Habitat International, 53, 115-122. https://doi.org/10.1016/j.habitatint.2015.11.001

You, H., Hu, X., \& Wu, Y. (2018). Farmland use intensity changes in response to rural transition in Zhejiang province, China. Land Use Policy, 79, 350-361. https://doi.org/10.1016/j.landusepol.2018.08.029

Zhang, K., Douglas, B.C., \& Leatherman, S.P. (2004). Global warming and coastal erosion. Climatic Change, 64(1-2), 41-58. https://doi.org/10.1023/b:clim.0000024690.32682.48

Zhu, X. (2004). Fractal character of China bedrock coastline. Chinese Journal of Oceanology and Limnology, 22(2), 130-135. https://doi.org/10.1007/bf02842583 
Yizhou Wu et al. 